\title{
cagA Positive Helicobacter pylori in Brazilian Children Related to Chronic Gastritis
}

\author{
Luciano Lobo Gatti ${ }^{1,2}$, Roger de Lábio', \\ Luiz Carlos da Silva ${ }^{3}$, Marília de Arruda Cardoso Smith² \\ and Spencer Luiz Marques Payão ${ }^{1,2}$
}

\author{
${ }^{1}$ Hemocentro - School of Medicine of Marília, Department of \\ Genetic and Molecular Biology, FAMEMA, Marília, São Paulo,; \\ ${ }^{2}$ Department of Genetic, UNIFESP/EPM, São Paulo, SP; \\ ${ }^{3}$ Department of Pathology, FAMEMA, Marília, São Paulo, Brazil
}

\begin{abstract}
Helicobacter pylori is a spiral-shaped Gram-negative bacterium. It colonizes the gastric mucosa of humans and persists for decades if not treated. Helicobacter pylori infection affects more than half of the world's population and invariably results in chronic gastritis. The $\operatorname{cag} A$ gene is present in about 60 to $70 \%$ of $H$. pylori strains; it encodes a high-molecular-weight protein (120 to $140 \mathrm{kDa})$ and several investigators have noted a correlation between strains that possess $\operatorname{cag} A$ and the severity of gastric mucosal inflammation. We examined the relation between cagA status in $H$. pylori strains and chronic gastritis with inflammatory processes in children from Marília, São Paulo, Brazil. Onehundred-twenty-one children were analyzed histopathologically and by polymerase chain reaction (PCR) to detect $H$. pylori and $\operatorname{cagA}$. We then looked for an association between cagA presence and inflammatory infiltration. Using histology and PCR, we found $47 \% \mathrm{H}$. pylori positive infection; 29 children were diagnosed with chronic gastritis, while 28 showed normal mucosa by histopathological analysis. $\mathrm{CagA}$ presence was genotyped in both groups, and an inflammatory infiltrate was studied in all infected children with chronic gastritis. We found cagA strains in 20 of $29(69 \%)$ children with chronic gastritis and 18 of 28 (64\%) with normal mucosa, demonstrating a strong relationship between the strains and the inflammatory process. We found a positive association between an inflammatory process associated with $H$. pylori of cagA+ strains and chronic gastritis development.
\end{abstract}

Key Words: Helicobacter pylori infection, cagA, inflammatory infiltrate.

Helicobacter pylori is a spiral-shaped Gram-negative bacterium. It colonizes the gastric mucosa of humans and persists for decades if not treated [1]. Helicobacter pylori infection affects more than half of the world's population and invariably results in chronic gastritis. The clinical results of this infection range from asymptomatic gastritis to peptic ulcers and gastric cancer [2]. The infection is mostly asymptomatic, and most of the infected population never manifests clinically significant conditions. However, some individuals develop diseases, such as peptic ulcers and mucosa-associated lymphoid tissue lymphoma $[1,3,4]$. Several studies suggest progressive gastric mucosal damage induced by this pathogen [5], since clinical symptoms of gastric disorders appear most frequently in adults, while $H$. pylori acquisition occurs in childhood [6].

However, the role of $H$. pylori in the genesis of gastric disorders in children and in adults is still controversial, since there is no specific clinical manifestation related to $H$. pylori infection and not all infected people develop gastric problems [7]. Host-pathogen interactions involving environmental, host and bacterial factors seem to contribute to the onset and

Received on 24 January 2006; revised 28 July 2006.

Address for correspondence: Dr. Luciano Lobo Gatti. Hemocentro - Faculdade de Medicina de Marília, Disciplina de Genética e Biologia Molecular. Rua Lourival Freire, $n^{0}$. 240, Zip code: 17519-050 Bairro Fragata. Marília - São Paulo - Brasil. FAX: (14) 3433-0148 Phone: (14) 3402-1855. E-mail: lobogatti@yahoo.com.br.

The Brazilian Journal of Infectious Diseases 2006;10(4):254-258. (C) 2006 by The Brazilian Journal of Infectious Diseases and Contexto Publishing. All rights reserved. progression of gastric diseases.

Experience with other bacterial pathogens lead us to believe that $H$. pylori strain-specific factors may influence the pathogenicity of different $H$. pylori, such as vacuolating cytotoxin (VacA) and cytotoxin-associated protein (CagA), which have been identified [8-12].

Only $50 \%$ to $65 \%$ of $H$. pylori strains produce an $87 \mathrm{kDa}$ cytotoxin that induces vacuolation of HeLa or primary gastric epithelial cells in vitro $[9,11,13]$. Specific vacA genotypes were characterized by differences in the signal sequence and the middle region of the gene in isolates obtained from U.S. subjects [14,15]. A vacA signal sequence type s1, but not type s2, was closely associated with in vitro cytotoxin activity.

The cagA gene is present in about $60 \%$ to $70 \%$ of $H$. pylori strains; it encodes a high-molecular-weight protein (120 to $140 \mathrm{kDa}$ ) [9,16]. The CagA gene is a marker for the presence of a transposable element, the chromosome pathogenicity island (Cag PAI) of $40 \mathrm{~kb}$, containing about 30 genes similar to the type IV secretion system acquired by $H$. pylori through horizontal transfer. The Cag PAI gene products have been shown to be involved in the induction of pro-inflammatory chemokines released by host cells $[17,18]$. Several investigators have noted a correlation between strains that possess cagA and the severity of gastric mucosal inflammation $[19,20]$.

We evaluated the relation between cagA status and chronic gastritis with inflammatory process in children in Marília, São Paulo, Brazil.

\section{Material and Methods}

Patients, endoscopy and biopsies

The subjects included in this study consisted of 121 
consecutive child patients presenting recurrent abdominal pain (range 1-16 years, mean age 8.6) seen at the Marilia School of Medicine Gastroenterology Outpatient Clinic of Pediatrics, in Marília, São Paulo, Brazil. After clinical evaluation, standard laboratory examination, $\mathrm{x}$-ray and ultrasonography, all patients underwent upper-gastrointestinal endoscopy. Four biopses were obtained from each patient from both the gastric antrum and the corpus. One corpus and one antrum specimen were used for each rapid urease test and DNA extraction, and two specimens of each were used for histological analysis.

Endoscopic forceps were sterilized in 2\% glutaraldehyde solution for a minimum of 20 minutes between experiments. This study was approved by the institutional ethics committee, and written informed consent was obtained from the parents of all patients.

\section{Rapid urease test and histology}

One corpus and one antrum sample were used for a rapid urease test employing STAT-PAK ${ }^{\circledR}$, following the manufacturer's instructions, and two corpus and two antrum samples were used for histopathological examination, including $H$. pylori detection using the updated Sydney System [21].

\section{DNA extraction}

DNA for PCR was extracted directly from one corpus and one antrum biopsy, using the QIAamp tissue kit provided by Qiagem.

\section{Helicobacter pylori detection}

PCR assays were performed with approximately 100 $\mu$ g of total DNA, using two different sets of oligonucleotides; one amplifies a $411 \mathrm{bp}$ fragment, corresponding to the urease gene [22], and the other amplifies a 298bp fragment, corresponding to a gene encoding a $26 \mathrm{kDa}$ antigenic protein specific for $H$. pylori [23]. In each experiment, positive and negative controls were included (Figure 1A).

\section{CagA genotyping}

For cagA detection, primers cag1/cag2 [31] and cag3/cag4 [24] amplified fragments of 232 bp and 348 bp respectively (Figure 1B, C and D). Oligonucleotide sequences, and PCR conditions are described in Table 1.

\section{Statistical methods}

Statistical analysis was performed by the two-tailed $\chi^{2}$ test and Fisher's exact test. Significance was set at $<0.05$.

\section{Results}

Detection of $H$. pylori presence in gastric mucosa by histopathological analysis and PCR

Fifty-seven children (47\%) of 121 were positive for $H$. pylori presence in gastric mucosa by histopathological analysis and by PCR. Twenty-nine children were diagnosed to have chronic gastritis and 28 had normal gastric mucosa.

The percentage of $H$. pylori-positive children with chronic gastritis was $51 \%$ (29 patients), while $49 \%$ of the children (28 patients) displayed normal mucosa.

\section{cagA status and chronic gastritis}

Twenty (69\%) of 29 children with chronic gastritis and 18 (64\%) of 28 children with normal mucosa showed cagApositive strains. A significant association between children with chronic gastritis and $\operatorname{cag} A$ presence was observed $(\mathrm{P}=0.041)$. No significant association between cagA presence and score differences in mononuclear cell infiltration was observed.

cagA status and neutrophilic inflammatory activity in chronic gastritis

Twenty children were found to be infected with $H$. pylori cagA+, and 16 (80\%) showed neutrophilic inflammatory activity on histological analysis (four with score 00 and 12 with score 01 ), while four (20\%) did not have this activity (P= 0.032 , Figure 2).

Nine of 29 children with chronic gastritis were infected by cagA-negative $H$. pylori. Three of the nine children showed neutrophilic inflammatory activity histologically (two with score 01 and one with score 00 ) and six of the nine did not show this infiltrate. The difference was not significant.

\section{Discussion}

Studies suggest that infection with cagA positive $H$. pylori strains induces a marked inflammatory response, with a great density of polymorphonuclear cells in the gastric mucosa and high levels of serum tumor necrosis alpha-factor and gastrin, which are seen as markers of inflammation in H.pylori infection, when compared with the cagA negative strains [25].

The cytotoxin-associated gene $\operatorname{cag} A$ was the first gene found to be differentially present in $H$. pylori isolates; it is considered a marker for cag pathogenicity. In addition to other putative virulence properties encoded by the cag pathogenicity island, several genes of the island encode proteins that enhance the gastric inflammatory response to infection, such as interleukin-8.

A high degree of polymophonuclear infiltration for long periods of time may be a risk factor for carcinogenesis, since the oxidative burst produced by the disintegration of cells in the gastric mucosa liberates substances with mutagenic potential [26].

Demirturt et al. studied the association between $\operatorname{cagA}$ positive strains and histopathological findings in dyspeptic patients and found a significant association between severe inflammation and cagA-positive strains [27]. We found a strong association between cagA presence and polymophonuclear infiltration in chronic gastritis $(\mathrm{P}=0.032)$. 
Table 1. Oligonucleotides and PCR conditions

\begin{tabular}{llcl}
\hline Primer & Sequence (5'- 3') & Reference & PCR Condition \\
\hline Cag1 & ATGACTAACGAAACTATTGATC & 31 & $94^{\circ} \mathrm{C} 5^{\prime}, 40$ cycles $94^{\circ} \mathrm{C} 1^{\prime} / 52^{\circ} \mathrm{C} 1^{\prime} / 72^{\circ} \mathrm{C}, 7^{\prime} 72^{\circ} \mathrm{C}$ \\
Cag2 & CAGGATTTTGATCGCTTTATT & 31 & \\
Cag3 & GATAACAGGCAAGCTTTTGAGG & 24 & $94^{\circ} \mathrm{C} 5^{\prime}, 40$ cycles $94^{\circ} \mathrm{C} 1^{\prime} / 56^{\circ} \mathrm{C} 1^{\prime} / 72^{\circ} \mathrm{C}, 7^{\prime} 72^{\circ} \mathrm{C}$ \\
Cag4 & CTGCAAAAGATTGTTTGCGAGA & 24 & \\
H3 & TGGCGTGTCTATTGACAGCGAGC & 22 & $94^{\circ} \mathrm{C} 5^{\prime}, 40$ cycles $94^{\circ} \mathrm{C} 1^{\prime} / 60^{\circ} \mathrm{C} 1^{\prime} / 72^{\circ} \mathrm{C}, 7^{\prime} 72^{\circ} \mathrm{C}$ \\
H4 & CCTGCTGGGCATACTTCACCATG & 22 & \\
H5 & GCCAATGGTAAATTAGTT & 23 & $94^{\circ} \mathrm{C} 5^{\prime}, 40$ cycles $94^{\circ} \mathrm{C} 1^{\prime} / 43^{\circ} \mathrm{C} 1^{\prime} / 72^{\circ} \mathrm{C}, 7^{\prime} 72^{\circ} \mathrm{C}$ \\
H6 & CTCCTTAATTGTTTTAC & 23 & \\
Hp1.1 & CTGGAGARACTAAGYCCTCC & 32 & $94^{\circ} \mathrm{C} \mathrm{5}, 40$ cycles $94^{\circ} \mathrm{C} 1^{\prime} / 59^{\circ} \mathrm{C} 1^{\prime} / 72^{\circ} \mathrm{C}, 7^{\prime} 72^{\circ} \mathrm{C}$ \\
HPX2 & GAGGAATACTCATTGCGAAGGCGA & 32 & \\
\hline
\end{tabular}

Figure 1 A. 2\% agarose gel after PCR amplification of Helicobacter pylori DNA detection using H3H4 primers (298 bp) (lane1); HP1.1/HPX2 primers (150 bp) (lane 2) and h5/h6 primers (411 bp) (lane 3); M,100 bp DNA Marker. B. 2\% agarose gel after PCR amplification of cagA detection using cag1/cag2 primers (232 bp). Lanes 1-13. patients; C- negative control, C+ positive control and $\mathrm{M}=100$ bp DNA Marker. C. Autoradiograph after hybridization with a cagA-specific chemiluminescent probe. Lanes 2,3,4,5,7,8,9,10,11 and 12, positive strains after hybridization; Lanes 3 and 8, negative strains for cagA presence. C+ positive control. D. $2 \%$ agarose gel after PCR amplification of $H$. pylori DNA using cag3/cagA4 primer. Lanes $\mathrm{C}+$, positive control, 1 and 5 negative strains and 2-4 positive strains for cagA presence. C-, negative control and M, 100 bp DNA Marker.
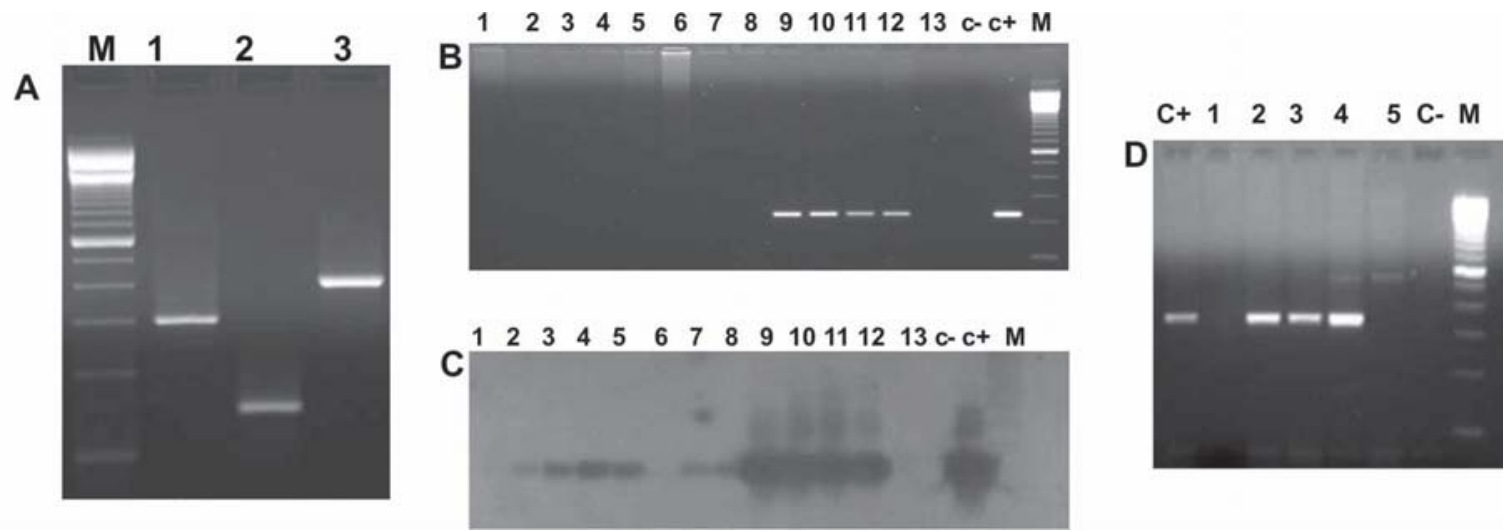

Figure 2. Association between cagA+ and inflammatory activity.

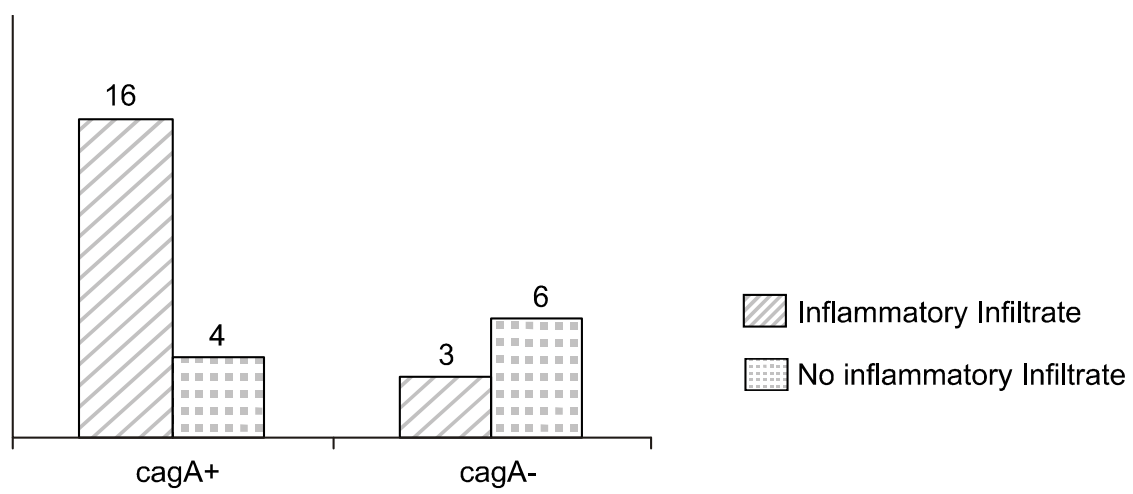

Frequency of inflammatory activity in children with chronic gastric problems in relation to $\operatorname{cagA}$. * Significant difference $(\mathrm{P}=0.032)$. 
This association was not observed in cagA-negative strains. Studies haveshown that increased mucosal polymorphonuclear cell infiltration observed in patients infected with cagA positive strains is linked to enhanced interleukin-8 (IL-8) secretion by the gastric mucosa [17]. However, cagA-negative mutants that do not contain CagA protein are still able to induce enhanced IL-8 secretion, which raises the hypothesis that the $\operatorname{cag} A$ gene is not uniquely responsible for this ability [28].

Oliveira et al. (2003) found an association between cagA presence with more marked antral inflammation in duodenal ulcer and gastric carcinoma in Brazilian adults [29]. Ribeiro et al. (2003) studied Brazilian isolates and suggested that patients colonized with cagA positive $H$. pylori strains are at increased risk for developing peptic ulceration [30].

We did not find any association between cagA-positive strains and chronic gastritis, but $80 \%$ of patients with chronic gastritis were cagA-positive, suggesting that other bacterial factors are involved in disease generation. It may be that host factors, such as interleukin-1 polymorphism and cagA presence, are important for the development of gastric inflammatory process in $H$. pylori infection in children.

Of the 28 children with normal mucosa by histopathological analysis, 64\% revealed a cagA positive infection, suggesting that these children had an initial infection by this bacterium. We will be following up on these children, because $H$. pylori is a chronic infection and can eventually develop into chronic gastritis and other gastric complications.

\section{Acknowledgements}

This work was supported by the Fundação de Amparo à Pesquisa do Estado de São Paulo (FAPESP, BRAZIL) grant numbers: 1998/15456-8, 2000/13996-7, a graduate student fellowship for LLG (FAPESP no. 2000/05590-0), and by the Faculdade de Medicina de Marília (FAMEMA).

\section{References}

1. Blaser M.J. Ecology of Helicobacter pylori in the human stomach. J Clin Invest 1997;100:759-62.

2. Sipponem P., Hyvarinen H. Role of Helicobacter pylori in the pathogenesis of gastritis, peptic ulcer and gastric cancer. Scand J Gastroenterol 1993;28:3-6.

3. Marshall B.J. Unindentified curved bacilli on gastric epithelium in active chronic gastritis. Lancet 1983;983:1273-5.

4. Blaser M.J. Not all Helicobacter pylori strains are created equal: Should all be eliminated? Lancet 1997;349:1020-2.

5. Ernst P.B., Gold B.D. Helicobacter pylori in childhood: new insights for managing infection in children. J Pedriatr Gastroenterol Nutr 1999;28:462-73.

6. Bonamico M., Mariani P., Magliocca F.M., et al. Helicobacter pylori duodenal colonization in children. 1997;86:356-360.

7. Gormally S.M., Prakash N., Durvin M.T., et al. Association of symptoms with Helicobacter pylori infection in children. J Pediatr 1995;126:753-6.
8. Covacci A.S., Censini M., Bugnoli R., et al. Molecular characterization of the $128-\mathrm{kDa}$ immunodominant antigen of Helicobacter pylori associated with cytotoxicity and duodenal ulcer. Proc Natl Acad Sci 1993; 90: 5791-5.

9. Cover T.L., Dooley C.P., Blase M.J. Characterization of and human serologic response to proteins in Helicobacter pylori broth culture supernatants with vacuolizing cytotoxin activity. Infect. Immun 1990;58:603-10.

10. Crabtree J.E., Figura N., Taylor J.D., et al. Expression of 120 kilodalton protein and cytotoxicity in Helicobacter pylori. J Clin Pathol 1992;45:733-4.

11. Figura N.P., Guglielmetti A., Rossoline A., et al. Cytotoxin production by Campylobacter pylori strains isolated from patients with peptic ulcers and from patients with chronic gastritis only. J Clin Microbiol 1989;27:225-6.

12. Leunk R.D., Johnson P.T., David B.C., Kraft W.G., Morgan DR. Cytotoxin activity in broth-culture filtrates of Campylobacter pylori. J Med Microbiol 1998;26:93-9.

13. Cover T.L., Tummuru M.K.R., Cao P., et al. Divergence of genetic sequences for the vacuolating cytotoxin among Helicobacter pylori strains. J Biol Chem 1997;269:10566-73.

14. Atherton J.C., Cao P., Peek R.M., et al. Mosaicism in vacuolating cytotoxin alleles of Helicobacter pylori. J Biol Chem 1995;270:17771-7.

15. Atherton J.C., Peek R.M., Tham K.T., et al. Clinical and Pathological importance of heterogeneity in vacA, the vacuolating cytotoxin gene of Helicobacter pylori. Gastroenterol 1997;112:92-9.

16. Tummuru M.K.R., Cover T.L., Blaser M.J. Cloning and expression of a high-molecular-mass major antigen of Helicobacter pylori: evidence of linkage to cytotoxin production. Infect Immun 1993;61:1799-809.

17. Crabtree J.E., Covacci A., Farmery S.M., et al. Helicobacter pylori induced interleukin-8 expression in gastric epithelial cell is associated with cagA positive phenotype. J Clin Pathol 1995;48:41-5.

18. Huang J., O’Toole P.W., Doig P., Trust T.J. Stimulation of interleukin-8 in epithelial cell line by Helicobacter pylori. Infect Immun 1995;63:1732-8.

19. Blecker V., Mckeithan T.W., Hant J., Kirchner B.R. Resolution of Helicobacter pylori associated gastric lymphoproliferative disease in a child. Gastroenterology 1995;109:973-7.

20. Queiroz D.M.M., Mendes E.M., Rocha G.A., et al. CagA positive Helicobacter pylori and risk for developing gastric carcinoma in Brazil. Int J Cancer 1998;78:135-9.

21. Dixon M.F., Genta R.M., Yardley J.H., Correa P. Classification and grading of gastritis: The update Sydney System. Am J Surg Pathol 1996;20:1161-81.

22. Clayton C.L., Kleanthoris H., Coates P.J., et al. Sensitive detection of Helicobacter pylori by using polymerase chain reaction. J Clin Microbiol 1992;30:192-200.

23. Hammar M., Tyszkiewecz T., Wadstrom T., O’ Toole PW. Rapid detection of Helicobacter pylori in gastric biopsy materail by polymerase chain reaction. J Clin Microbiool 1992;30:54-8.

24. Peek R.M., Miller G.G., Tham K.T., et al. Detection of Helicobacter pylori gene expression in human gastric mucosa. J Clin Microbiol 1995;33:28-32. 
25. Saruc M., Demir M.A., Kucukmetin N., et al. Histological and clinical predictive value of determination of tissue CagA status by PCR in Helicobacter pylori infected patients; results of the large population based study in western Turkey. Hepatogastroenterology 2002;49:878-81.

26. Correa P. Helicobacter pylori and gastric carcinogenesis. Amer. J Surg Pathol 1995;19(suppl.1).S37-S43.

27. Demirtürk L., Özel AM., Yazgan Y., et al. CagA status in dyspeptic patients with and without peptic ulcer disease in Turkey: Association with histopathologic findings.Helicobcater 2001;6:163-8.

28. Sharma A.S., Tummuru M.K., Miller G.G., Blaser M.J. Interleukin-8 response of gastric epithelial cell lines to Helicobacter pylori stimulation in vitro. Infect Immunity 1995;63:1681-7.
29. Oliveira A.G., Santos A., Guerra J.B., et al. babA2 and cagA positive Helicobacter pylori strains are associated with duodenal ulcer and gastric carcinoma in Brazil. J Clin Microbiol 2003;41:3964-6.

30. Ribeiro M.L., Godoy A.P.O., Benvengo Y.H.B., et al. Clinical relevance of the cagA, vacA and iceA genotypes of Helicobacter pylori in Brazilian clinical isolates. FEMS Immunol Med Microbiol 2003;36:181-5.

31. Gatti L.L., Agostinho F.J., Labio R.W., et al. Helicobacter pylori and cagA and vacA gene status in children from Brazil with chronic gastritis. Clin Med Exp Med 2003;3:166-72.

32. Scholte G.H.A., van Doorn L.J., Quint W.G.V., Linderman J. Polymerase Chain Reaction for detection of Helicobacter pylori in formaldehyde-sublimate fixed, paraffin-embedded gastric biopsies. Diag Mol Pathol 1997;6:238-43. 